Article

\title{
In-Vitro Antioxidant, Hypoglycemic Activity, and Identification of Bioactive Compounds in Phenol-Rich Extract from the Marine Red Algae Gracilaria edulis (Gmelin) Silva
}

\author{
Thilina L. Gunathilaka ${ }^{1}$, Kalpa W. Samarakoon ${ }^{2}$, P. Ranasinghe ${ }^{3}$ and L. Dinithi C. Peiris ${ }^{1, *(D)}$ \\ 1 Department of Zoology, Faculty of Applied Sciences (Center for Instrumentation Facility \& Center for \\ Biotechnology), University of Sri Jayewardenepura, Nugegoda 10250, Sri Lanka; \\ gunathilakathilina2@gmail.com \\ 2 National Science and Technology Commission, Dudley Senanayake Mawatha, Colombo 8 00800, Sri Lanka; \\ kalpa.samarakoon@gmail.com \\ 3 Industrial Technology Institute, Halbarawa Gardens, Malabe 10115, Sri Lanka; pathmasiri@iti.lk \\ * Correspondence: dinithi@sci.sjp.ac.lk; Tel.:+94-714-018-537
}

Academic Editor: Lorenzo Di Cesare Mannelli

Received: 4 July 2019; Accepted: 3 October 2019; Published: 15 October 2019

check for updates

\begin{abstract}
Obesity and diabetes are major metabolic disorders which are prevalent worldwide. Algae has played an important role in managing these disorders. In this study, Gracilaria edulis, a marine red algae, was investigated for antioxidant and hypoglycemic potential using in vitro models. De-polysaccharide methanol extract of G. edulis was sequentially partitioned with hexane, chloroform, ethyl acetate, and antioxidants, and hypoglycemic potentials were evaluated using multiple methods. High antioxidant potential was observed in the ethyl acetate fraction in terms of ferric reducing antioxidant power, iron chelating, and DPPH and ABTS radical scavenging activities, while the crude methanol extract exhibited potent oxygen radical-absorbance capacity. Potent $\alpha$-amylase inhibitory activity was observed in the ethyl acetate fraction, while the ethyl acetate fraction was effective against $\alpha$-glucosidase inhibition. Glucose diffusion was inhibited by the ethyl acetate fraction at $180 \mathrm{~min}$, and the highest antiglycation activity was observed in both chloroform and ethyl acetate fractions. Additionally, gas chromatography-mass spectrometry analysis of the ethyl acetate fraction revealed the presence of several potent anti-diabetic compounds. In conclusion, G. edulis exhibited promising antidiabetic potential via multiple mechanisms. The ethyl acetate fraction exhibited the strongest hypoglycemic and antiglycation potential among the four fractions, and hence the isolation of active compounds is required to develop leads for new drugs to treat diabetes.
\end{abstract}

Keywords: Gracillaria edulis; methanol extract; fractionation; $\alpha$-amylase; $\alpha$-glucosidase; antiglycation; glucose diffusion

\section{Introduction}

The incidences of type 2 diabetes and obesity have increased globally due to rapid urbanization and unhealthy diets. More than $90 \%$ of patients with diabetes mellitus are either overweight or obese [1]. Diabetes mellitus is a chronic disorder that is linked with persistent hyperglycemia due to the deficiency of insulin secretion. The World Health Organization (WHO) has estimated that by 2035, the incidence of diabetes mellitus and impaired glucose tolerance will increase by up to 592 million and 471 million people, respectively [2]. Type 1 diabetes is widespread among Northern European countries, while type 2 diabetes is most common in African and South Asian countries. For instance, type 2 diabetes is prevalent among the Sri Lankan population [3]. According to recent statistics, one 
in every five Sri Lankan adults either suffers from diabetes or is in the prediabetes stage [4]. The consumption of more refined fast-release staple carbohydrate food is considered as the major cause for the progression of obesity. Carbohydrate-rich diets release glucose quickly into the bloodstream, thus increasing the levels of blood sugar and insulin [5]. High blood glucose level is linked with increased risk of hypertension, retinopathy, nephropathy, neuropathy, and macrovascular diseases. These health complications result in an increased risk of morbidity and mortality, and hence reduce the life expectancy of diabetic patients [4].

The inhibition of carbohydrate digestive enzymes- $\alpha$-amylase and $\alpha$-glucosidase - is one of the significant alternatives to the management of chronic hyperglycemia in diabetic patients [1]. Polyphenols purified from plants are good inhibitors of vital enzymes responsible for carbohydrate digestion. The enzymes alpha amylase and $\alpha$-glucosidase are involved in carbohydrate metabolism, and act synergistically to digest starch [6]. Alpha amylase hydrolyzes the alpha bonds present in insoluble starch molecules, while $\alpha$-glucosidase catalyzes the final step of carbohydrate digestion to convert disaccharides into glucose. The inhibition of such enzymes leads to a reduction of starch breakdown and an increase in postprandial blood glucose level; thus, enzyme inhibitors can be used as therapeutic agents for the development of novel drugs to treat diabetes [6].

Recent investigations have reported an association between obesity and chronic inflammation in adipose tissues. As a result of obesity, the amount of adipose tissue tends to increase and the tissue undergoes molecular and cellular alterations. Adipocytokines secreted by the adipocytes in adipose tissues can induce production of reactive oxygen species, thus leading to oxidative stress [7]. Oxidative stress is tightly linked with the pathophysiological process of chronic inflammatory conditions such as diabetes mellitus [8]. Therefore, researchers have primarily focused on natural products to discover novel preventive and regenerative therapies to combat oxidative stress and postprandial hyperglycemia with minimum side effects.

Marine seaweeds rich in bioactive metabolites play a significant role in the development of novel drugs and nutraceuticals. Due to the bioactive compounds they contain-namely polyphenols, sterols, alkaloids, flavonoids, tannins, proteins, essential fatty acids, enzymes, vitamins, and carotenoids-marine seaweeds are able to withstand harsh environments [9]. Gracilaria edulis (Gmelin) Silva is a red algae belonging to the family Gracilariaceae, and it has attracted widespread attention due to its biological and pharmacological properties and various therapeutic benefits such as antidiabetic, antioxidant, antimicrobial, anticoagulant, anti-inflammatory, and antiproliferative activities [10]. Shanura et al. [11] established the anti-inflammatory activity of methanol extract and fractions of G. edulis against lipopolysaccharide-induced inflammatory responses, while Koneri and Jha [12] documented the antidiabetic potential of methanol extracts of G. edulis against fructose-induced type 2 diabetes mellitus in male rats. Patra and Muthuraman [13] revealed the anticancer activity of ethanol extracts of G. edulis against ascites tumors in mice. Although past studies focused on several biological properties of G. edulis, this is the first study carried out in Sri Lanka to investigate the antioxidant and hypoglycemic activities of G. edulis using multiple in vitro mechanisms. The present study aimed to appraise the antidiabetic potential of G. edulis through inhibitory activities of carbohydrate digestive enzymes, glucose diffusion, and protein glycation. We also attempted to identify the bioactive compounds present in G. edulis that are responsible for the above pharmacological activities.

\section{Results}

\subsection{Quantification of Total Phenolic, Flavonoid, and Alkaloid Contents of G. edulis}

Results obtained for the crude methanol extract and four fractions of G. edulis with increasing polarity were used to evaluate the total phenolic, flavonoid, and alkaloid contents of G. edulis. These results are shown in Table 1. The alkaloid content in the crude methanol extract and in the hexane and chloroform fractions was higher than the phenol and flavonoid contents, whereas the phenol content in the ethyl acetate and aqueous fractions was higher than the flavonoid and alkaloid contents. 
Table 1. Phenol, flavonoid, and alkaloid contents of crude methanol extract and fractions of Gracillaria edulis.

\begin{tabular}{cccc}
\hline Extract/Fraction & $\begin{array}{c}\text { TPC } \\
(\mu \text { GAE/g) }\end{array}$ & $\begin{array}{c}\text { TFC } \\
(\mu \mathbf{g ~ Q E} / g)\end{array}$ & $\begin{array}{c}\text { Total Alkaloids } \\
(\mu \mathrm{g} \text { PE/g) }\end{array}$ \\
\hline Crude methanol extract & $1007.81 \pm 54.21^{\mathrm{a}}$ & $541.02 \pm 51.84^{\mathrm{a}}$ & $7177.72 \pm 63.04^{\mathrm{a}}$ \\
Hexane fraction & $760.85 \pm 37.75^{\mathrm{b}}$ & $688.60 \pm 9.55^{\mathrm{a}}$ & $1656.97 \pm 45.80^{\mathrm{b}}$ \\
Chloroform fraction & $560.85 \pm 55.08^{\mathrm{c}}$ & $289.39 \pm 9.55^{\mathrm{b}}$ & $2875.54 \pm 22.29^{\mathrm{c}}$ \\
Ethyl acetate fraction & $2414.51 \pm 50.34^{\mathrm{d}}$ & $1461.49 \pm 75.22^{\mathrm{c}}$ & $1073.75 \pm 45.88^{\mathrm{b}}$ \\
Aqueous fraction & $1704.69 \pm 43.16^{\mathrm{e}}$ & $786.95 \pm 62.04^{\mathrm{d}}$ & $522.34 \pm 67.13^{\mathrm{d}}$ \\
\hline
\end{tabular}

TPC: total phenol content; TFC: total flavonoid content; GAE: gallic acid equivalent; QE: quercetin equivalent; PE: Piperine equivalent. Data presented as mean \pm standard deviation $(n=4)$. Mean values in a column superscripted by different letters $\left({ }^{\mathrm{a}-\mathrm{e}}\right)$ are significantly different at $p<0.05$.

The total phenolic content in the ethyl acetate fraction $(2414.51 \pm 50.34 \mu \mathrm{g}$ GAE/g) was higher than that in the crude methanol extract and the hexane, chloroform, and aqueous fractions. The lowest total phenolic content was observed in the chloroform fraction. Similarly, a significant difference was observed in the phenolic content of the crude methanol extract and the four fractions $(p<0.05)$. The total flavonoid content of the crude methanol extract and all fractions increased in the order chloroform fraction $<$ crude methanol extract $<$ hexane fraction $<$ aqueous fraction $<$ ethyl acetate fraction, with respective contents of $289.39 \pm 9.55,541.02 \pm 51.84,688.60 \pm 9.55,786.95 \pm 62.04$, and $1461.49 \pm 75.22 \mu \mathrm{g} \mathrm{QE} / \mathrm{g}$. Among the crude methanol extract and four fractions, total alkaloid content decreased in the order crude methanol extract $>$ chloroform fraction $>$ hexane fraction $>$ ethyl acetate fraction $>$ aqueous fraction, with respective values of $7177.72 \pm 63.04,2875.54 \pm 22.29,1656.97 \pm 45.80$, $1073.75 \pm 45.88$, and $522.34 \pm 67.13 \mu \mathrm{g} \mathrm{PE} / \mathrm{g}$.

\subsection{In Vitro Antioxidant Activity}

The antioxidant capacity of crude methanol extract and fractions of G. edulis were determined using 1,1-diphenyl-2-picrylhydrazine (DPPH) and 2,2'-azino-bis (3-ethylbenzothiazoline-6-sulphonic acid) (ABTS) radical scavenging activities, ferrous ion chelating assay, ferric reducing antioxidant power, and oxygen radical-absorbance capacity. The results obtained for the antioxidant capacity are presented in Table 2.

The highest DPPH radical scavenging activity was observed in the ethyl acetate fraction $\left(\mathrm{IC}_{50}\right.$ : $3.17 \pm 0.04 \mathrm{mg} / \mathrm{mL}$ ) and the crude methanol extract $\left(\mathrm{IC}_{50}: 3.19 \pm 0.02 \mathrm{mg} / \mathrm{mL}\right.$ ). By comparison, the standard Trolox had free radical scavenging activity of $\mathrm{IC}_{50}: 0.011 \mathrm{mg} / \mathrm{mL}$. In this study, the reduction of DPPH occurred in a concentration-dependent manner, as observed from the high reduction of DPPH (higher radical activity) at $3.75 \mathrm{mg} / \mathrm{mL}$ concentrations (Figure A1). The most potent ABTS radical scavenging activity was observed in the ethyl acetate fraction $\left(\mathrm{IC}_{50}: 0.41 \pm 0.02 \mathrm{mg} / \mathrm{mL}\right)$, while the lowest activity was observed in the crude methanol extract $\left(\mathrm{IC}_{50}: 0.56 \pm 0.01 \mathrm{mg} / \mathrm{mL}\right)$. Moreover, a significant positive correlation was observed between the radical scavenging activity of DPPH $(r=0.91)$ and that of ABTS $(r=0.85)$ with the total phenol content of the ethyl acetate fraction. The highest ferrous iron chelating activity (FICA) was observed in the ethyl acetate fraction $\left(\mathrm{IC}_{50}\right.$ : $2.22 \pm 0.01 \mathrm{mg} / \mathrm{mL}$ ), while the lowest ferrous ion chelating activity was observed in the crude methanol extract $\left(\mathrm{IC}_{50}: 9.23 \pm 0.19 \mathrm{mg} / \mathrm{mL}\right.$ ); the standard EDTA (ethylenediaminetetraacetic acid) exhibited a chelating activity of $\mathrm{IC}_{50}: 0.019 \mathrm{mg} / \mathrm{mL}$. Ferric reducing antioxidant powder (FRAP) and oxygen radical absorbance capacity (ORAC) are the most frequent measures used to determine antioxidant activity, which is expressed as Trolox equivalent antioxidant capacity. The ethyl acetate fraction of G. edulis showed the highest reducing ability $(8.51 \pm 0.09 \mathrm{mg} \mathrm{TE} / \mathrm{g})$, while crude methanol extract $(1.61 \pm 0.19 \mathrm{mg} \mathrm{TE} / \mathrm{g})$ showed potent oxygen radical absorbance capacity. 
Table 2. $\mathrm{IC}_{50}$ values of methanol extract of G. edulis and fractions against antioxidant activity and activities equivalent to standards.

\begin{tabular}{|c|c|c|c|c|c|}
\hline \multirow{2}{*}{$\begin{array}{l}\text { Extract/ } \\
\text { Fraction }\end{array}$} & \multicolumn{3}{|c|}{$\mathrm{IC}_{50}(\mathrm{mg} / \mathrm{mL})$} & \multicolumn{2}{|c|}{$\begin{array}{l}\text { Activity Equivalent to } \\
\text { Standard (mg TE/g) }\end{array}$} \\
\hline & DPPH & ABTS & FICA & FRAP & ORAC \\
\hline Crude methanol extract & $3.19 \pm 0.02^{\mathrm{a}}$ & $0.56 \pm 0.01^{\mathrm{a}}$ & $9.23 \pm 0.19^{a}$ & $0.26 \pm 0.03^{a}$ & $1.61 \pm 0.19^{\mathrm{a}}$ \\
\hline Hexane fraction & $6.22 \pm 0.01^{b}$ & $0.54 \pm 0.01^{b}$ & $2.58 \pm 0.03^{b c}$ & $1.93 \pm 0.35^{b}$ & $0.57 \pm 0.07^{b c}$ \\
\hline Chloroform fraction & $3.29 \pm 0.02^{c}$ & $0.44 \pm 0.01^{\mathrm{c}}$ & $2.43 \pm 0.01^{\mathrm{c}}$ & $2.19 \pm 0.23^{b}$ & $0.77 \pm 0.05^{b}$ \\
\hline Ethyl acetate fraction & $3.17 \pm 0.04^{\mathrm{a}}$ & $0.41 \pm 0.02^{\mathrm{d}}$ & $2.22 \pm 0.01 \mathrm{bc}$ & $8.51 \pm 0.09^{c}$ & $1.44 \pm 0.29^{a}$ \\
\hline Aqueous fraction & $3.91 \pm 0.03^{\mathrm{d}}$ & $0.45 \pm 0.03^{c}$ & $2.71 \pm 0.02^{b}$ & $1.23 \pm 0.21^{\mathrm{d}}$ & $0.44 \pm 0.09^{c}$ \\
\hline Trolox (standard) & $0.011 \pm 0.00^{\mathrm{e}}$ & $0.008 \pm 0.00^{\mathrm{e}}$ & - & - & - \\
\hline EDTA (standard) & - & - & $0.019 \pm 00^{\mathrm{d}}$ & - & - \\
\hline
\end{tabular}

\subsection{In Vitro $\alpha$-Amylase Inhibitory Assay}

The $\alpha$-amylase inhibitory potential of G. edulis methanol extract and four fractions was evaluated using starch as the substrate and acarbose as the positive control. Acarbose, crude methanol extract, and the four fractions exhibited a dose-dependent enzyme inhibition (Figure A2).

The ethyl acetate fraction ( $\mathrm{IC}_{50}: 279.48 \pm 5.62 \mu \mathrm{g} / \mathrm{mL}$ ) of $\mathrm{G}$. edulis exhibited more potent $\alpha$-amylase inhibitory activity, whereas the lowest activity was observed in the hexane fraction $\left(\mathrm{IC}_{50}: 393.04 \pm 4.73 \mu \mathrm{g} / \mathrm{mL}\right.$ ) (Table 3) compared to the standard acarbose ( $\mathrm{IC}_{50}: 87.43 \mu \mathrm{g} / \mathrm{mL}$ ). The inhibition of the $\alpha$-amylase enzyme exhibited by the ethyl acetate fraction varied from $10 \%$ at $12.5 \mu \mathrm{g} / \mathrm{mL}$ to $64 \%$ at $400 \mu \mathrm{g} / \mathrm{mL}$ assay concentration.

Table 3. $\mathrm{IC}_{50}$ values exhibited by G. edulis methanol extract and methanol fractions against the inhibitory activity of the enzymes $\alpha$-amylase and $\alpha$-glucosidase and antiglycation activities.

\begin{tabular}{cccc}
\hline Extract/Fraction & $\begin{array}{c}\text { Alpha-Amylase } \\
(\mu \mathrm{g} / \mathbf{m L})\end{array}$ & $\begin{array}{c}\text { Alpha-Glucosidase } \\
(\mu \mathrm{g} / \mathrm{mL})\end{array}$ & $\begin{array}{c}\text { Anti-Glycation } \\
(\mu \mathrm{g} / \mathrm{mL})\end{array}$ \\
\hline Crude methanol extract & $349.59 \pm 2.44^{\mathrm{a}}$ & $102.24 \pm 0.89^{\mathrm{a}}$ & $702.33 \pm 12.72^{\mathrm{a}}$ \\
Hexane fraction & $393.04 \pm 4.73^{\mathrm{b}}$ & $163.90 \pm 5.23^{\mathrm{b}}$ & $637.53 \pm 6.21^{\mathrm{b}}$ \\
Chloroform fraction & $322.71 \pm 4.80^{\mathrm{c}}$ & $122.65 \pm 2.37^{\mathrm{c}}$ & $258.23 \pm 3.24^{\mathrm{c}}$ \\
Ethyl acetate fraction & $279.48 \pm 5.62^{\mathrm{d}}$ & $87.92 \pm 1.62^{\mathrm{d}}$ & $586.54 \pm 4.37^{\mathrm{b}}$ \\
Aqueous fraction & $376.49 \pm 12.14^{\mathrm{e}}$ & $148.57 \pm 1.87^{\mathrm{e}}$ & $723.78 \pm 12.81^{\mathrm{d}}$ \\
Acarbose (standard) & $87.43 \pm 0.59^{\mathrm{f}}$ & $0.38 \pm 0.06^{\mathrm{f}}$ & - \\
Rutin (standard) & - & - & $11.55 \pm 0.82^{\mathrm{e}}$ \\
\hline
\end{tabular}

Results are expressed as mean $\pm \mathrm{SD}(n=4) .{ }^{*} p<0.05$ compared with the respective standard. Mean values in a column superscripted by different letters $\left({ }^{\mathrm{a}-\mathrm{f}}\right)$ are significantly different at $p<0.05$.

\subsection{In Vitro $\alpha$-Glucosidase Inhibitory Assay}

All the fractions and the crude methanol extract of G. edulis exhibited a dose-dependent inhibition of the $\alpha$-glucosidase enzyme with different degrees of potential (Figure A3). The inhibitory activity on $\alpha$-glucosidase enzymes of the crude methanol extract and the fractions of G. edulis are presented in Table 3. The ethyl acetate fraction, which exhibited the lowest $\mathrm{IC}_{50}$ of $87.92 \pm 1.62 \mu \mathrm{g} / \mathrm{mL}$, was considered to be a more potent $\alpha$-glucosidase inhibitor than the crude methanol extract and the other three fractions. The inhibition of $\alpha$-glucosidase exhibited by the ethyl acetate fraction varied from $6 \%(4.16 \mu \mathrm{g} / \mathrm{mL})$ to $68 \%(133.3 \mu \mathrm{g} / \mathrm{mL})$. The hexane fraction, which had the highest $\mathrm{IC}_{50}$ of $163.90 \pm 5.23 \mu \mathrm{g} / \mathrm{mL}$, exhibited the weakest $\alpha$-glucosidase inhibitory activity. 


\subsection{Glucose Diffusion Inhibitory Activity}

The inhibitory activity of glucose diffusion was determined using a dialysis tube containing the sample and glucose that had been soaked in $\mathrm{NaCl}$ solution. The diffusion of glucose into the external solution was measured by glucose oxidase kit every $30 \mathrm{~min}$ for $3 \mathrm{~h}$. The effects of the methanol extract and the four fractions of G. edulis $(1000 \mu \mathrm{g} / \mathrm{mL}$ ) on glucose diffusion are represented in Figure 1. The inhibitory activity of acarbose or the reference drug was considered as $100 \%$, while the glucose diffusion of the control at $180 \mathrm{~min}$ was considered as $100 \%$ with a glucose concentration of $57.65 \pm 1.67 \mu \mathrm{g} / \mathrm{mL}$ in the external solution, compared to the acarbose standard $(22.79 \pm 0.47 \mu \mathrm{g} / \mathrm{mL})$. Among the tested fractions, the ethyl acetate fractions exhibited the maximum inhibition of glucose diffusion at $180 \mathrm{~min}$, and the glucose concentration of the external solution was found to be $38.15 \pm 1.11 \mu \mathrm{g} / \mathrm{mL}$. The inhibition of glucose diffusion by the hexane fraction $(52.01 \pm 0.96 \mu \mathrm{g} / \mathrm{mL})$ and aqueous fraction $(52.69 \pm 1.31 \mu \mathrm{g} / \mathrm{mL})$ were similar compared to the glucose concentration in the external solution (Table A1).

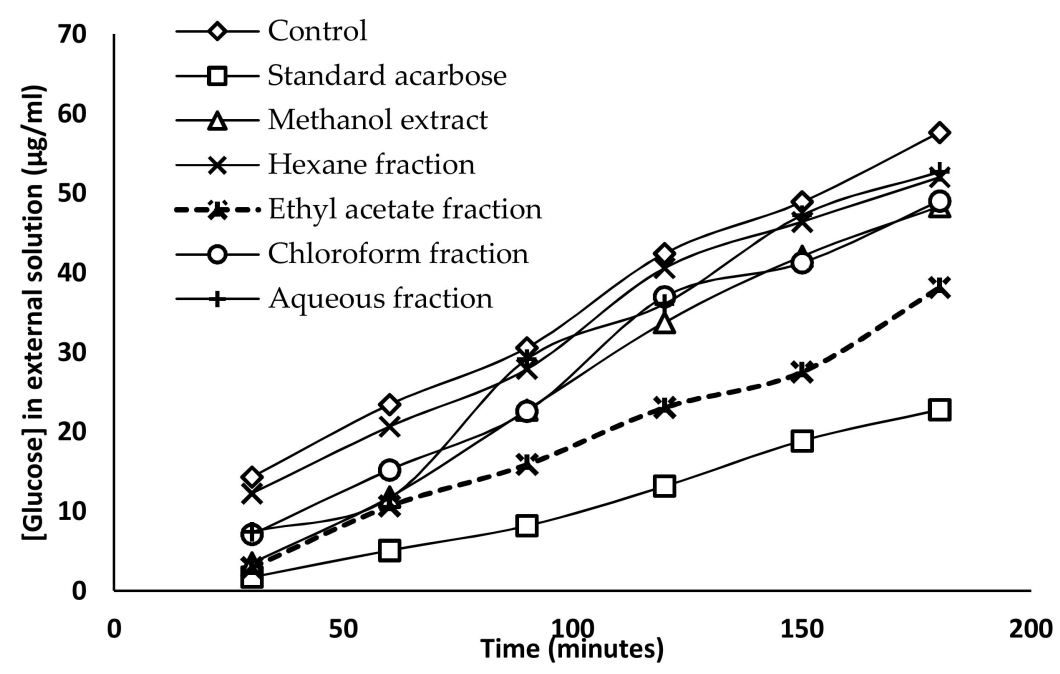

Figure 1. Effect of methanol extract and fractions of G. edulis $(1000 \mu \mathrm{g} / \mathrm{mL})$ on glucose diffusion through dialysis membrane compared to the standard acarbose and control. Data presented as means \pm standard deviation $(n=4)$.

\subsection{Antiglycation Activity}

The anti-glycation activity of the crude methanol extract and fractions of G. edulis was determined using bovine serum albumin as a protein source. The crude methanol extract and all four fractions showed dose-dependent antiglycation activity (Figure 2). As shown in Table 3, among the tested fractions, the most potent antiglycation activity was observed with the chloroform fraction $\left(\mathrm{IC}_{50}\right.$ : $258.23 \pm 3.24 \mu \mathrm{g} / \mathrm{mL}$ ), followed by the ethyl acetate fraction ( $\mathrm{IC}_{50}: 586.54 \pm 4.37 \mu \mathrm{g} / \mathrm{mL}$ ), compared to the standard rutin $\left(\mathrm{IC}_{50}: 11.55 \pm 0.82 \mu \mathrm{g} / \mathrm{mL}\right.$ ). The aqueous fraction, which had the highest $\mathrm{IC}_{50}$ value of $723.78 \pm 12.81 \mu \mathrm{g} / \mathrm{mL}$, exhibited the weakest antiglycation activity. 


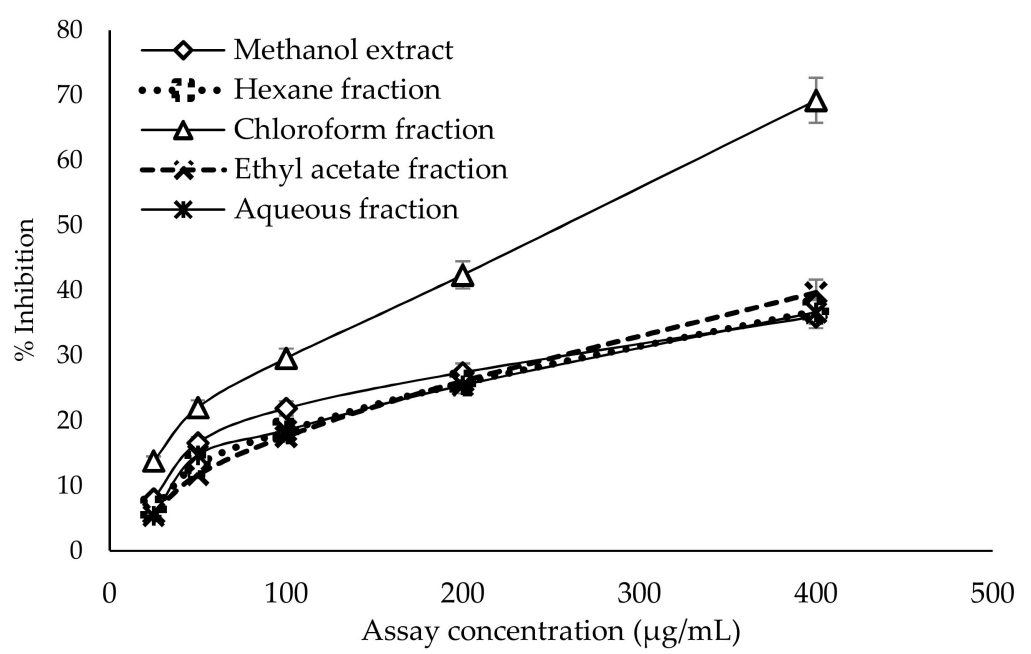

Figure 2. Dose-response relationship of methanol extract and its fractions of G. edulis for antiglycation activity determined by glucose-induced protein glycation and formation of protein-bound fluorescent advanced glycation end products. Data presented as mean \pm standard deviation $(n=4)$.

\subsection{GC-MS or Gas Chromatography-Mass Spectrometry Analysis of Extract and Solvent Fractions}

The ethyl acetate fraction of G. edulis, which showed promising biological activities, was subjected to gas chromatography-mass spectrometry (GC-MS) analysis. The chromatogram obtained for the ethyl acetate fraction is presented in Figure 3.

Based on the retention time and molecular weights of the GC-MS chromatogram, six compounds were identified in the ethyl acetate fraction of G. edulis. As listed in Table 4, these compounds included 2,5-dimethylhexane-2,5-dihydroperoxide, phthalic acid-6-ethyloct-3-yl 2-ethylhexyl ester, 1H-Indole-2-carboxylic acid, 6-(4-ethoxyphenyl)-3-methyl-4-oxo-4,5,6,7-tetrahydro-isopropylester, 2,3,5-Trichlorobenzaldehyde, Benz(b)1,4-oxazepine-4 (5H)-thione, 2,3-dihydro-2,8-dimethyl, and 2-acetoxymethyl-3-(methoxycarbonyl) biphenylene.

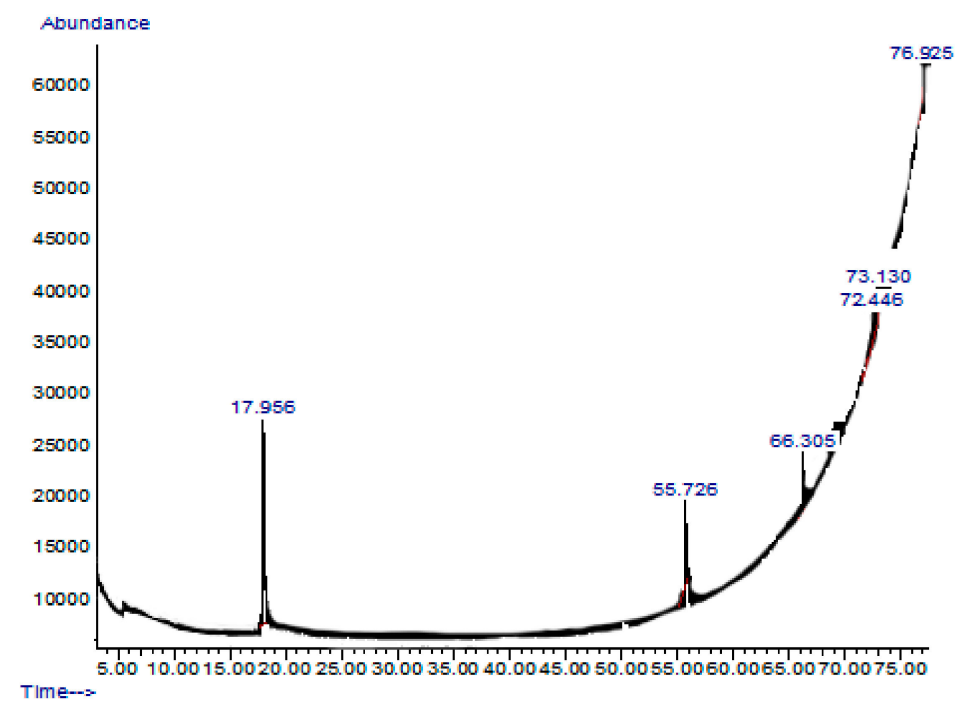

Figure 3. Chromatograms obtained from the gas chromatography-mass spectrometry (GC-MS) analysis of the ethyl acetate fraction of G. edulis. 
Table 4. Active compounds identified in the ethyl acetate fraction of G. edulis by gas chromatography-mass spectrometry (GC-MS) analysis.

\begin{tabular}{|c|c|c|c|c|}
\hline $\begin{array}{l}\text { Retention Time } \\
\text { and } \%\end{array}$ & Name & $\begin{array}{l}\text { Molecular } \\
\text { Formula }\end{array}$ & Compound Class & $\begin{array}{c}\text { Reported } \\
\text { Biological Activity }\end{array}$ \\
\hline $\begin{array}{c}17.956 \\
(54.27 \%)\end{array}$ & $\begin{array}{l}\text { 2,5-Dimethylhexane- } \\
\text { 2,5-dihydroperoxide }\end{array}$ & $\mathrm{C}_{8} \mathrm{H}_{18} \mathrm{O}_{4}$ & Organic compound & $\begin{array}{l}\text { Anti-inflammatory } \\
\text { Antioxidant }[14,15]\end{array}$ \\
\hline $\begin{array}{c}55.726 \\
(11.46 \%)\end{array}$ & $\begin{array}{l}\text { Phthalic acid-6-ethyloct-3-yl } \\
\text { 2-ethylhexyl ester }\end{array}$ & $\mathrm{C}_{26} \mathrm{H}_{42} \mathrm{O}_{4}$ & $\begin{array}{l}\text { Phthalic acid } \\
\text { derivative }\end{array}$ & $\begin{array}{c}\text { Anticancer } \\
\text { Antimicrobial [16] }\end{array}$ \\
\hline $\begin{array}{c}66.305 \\
(15.39 \%)\end{array}$ & $\begin{array}{c}\text { 1H-Indole-2-carboxylic acid,6-(4- } \\
\text { ethoxyphenyl)-3-methyl-4-oxo- } \\
\text { 4,5,6,7-tetrahydro-isopropyl } \\
\text { ester }\end{array}$ & $\mathrm{C}_{19} \mathrm{H}_{20} \mathrm{FNO}_{3}$ & Indole derivative & Antidiabetic $[17,18]$ \\
\hline $\begin{array}{c}72.446 \\
(10.93 \%)\end{array}$ & $\begin{array}{l}\text { 1,2-dimethoxy-4 (1,3-dimethoxy- } \\
\text { 1-propenyl) benzene }\end{array}$ & $\mathrm{C}_{13} \mathrm{H}_{18} \mathrm{O}_{4}$ & $\begin{array}{l}\text { Benzene } \\
\text { derivatives }\end{array}$ & Antifungal [19] \\
\hline $\begin{array}{c}73.130 \\
(1.52 \%)\end{array}$ & $\begin{array}{c}\text { Benz(b)1,4-oxazepine-4 } \\
(5 H) \text {-thione, } \\
\text { 2,3-dihydro-2,8-dimethyl }\end{array}$ & $\mathrm{C}_{11} \mathrm{H}_{13} \mathrm{NOS}$ & $\begin{array}{l}\text { Benzoxazepine } \\
\text { derivatives }\end{array}$ & $\begin{array}{l}\text { Anti-inflammatory } \\
\text { Antimicrobial [20] }\end{array}$ \\
\hline $\begin{array}{c}76.925 \\
(6.49 \%)\end{array}$ & $\begin{array}{l}\text { 2-acetoxymethyl-3- } \\
\text { (methoxycarbonyl)biphenylene }\end{array}$ & $\mathrm{C}_{17} \mathrm{H}_{14} \mathrm{O}_{4}$ & $\begin{array}{l}\text { Biphenyl } \\
\text { derivatives }\end{array}$ & Antibacterial [21] \\
\hline
\end{tabular}

Among these active compounds, $1 H$-Indole-2-carboxylic acid,6-(4-ethoxyphenyl)-3-methyl-4-oxo4,5,6,7-tetrahydro-isopropyl ester was identified as possessing antidiabetic activity through insulin sensitizing and glucose lowering effects [17]. In addition, most of the indole derivatives act as an activators of glycogen synthase enzyme, which involved in the glycogen synthesis pathway [18], while 2,5-dimethylhexane-2,5-dihydroperoxide has been identified to have antioxidant properties which help to prevent the development of oxidative stress related to diabetes [14,15].

\section{Discussion}

Recently, red marine algae has received significant attention due to its immense therapeutic benefits. However, only a limited number of studies have been performed on Sri Lankan marine algae. Therefore, to discover the therapeutic potential of tropical marine algae against diabetes and obesity, we studied G. edulis, a red algae from the northwestern coast of Sri Lanka to investigate its mechanisms of action.

Polyphenols, flavonoids, and alkaloids are secondary plant metabolites that have shown therapeutic benefits and are considered as potential sources of antioxidants. The polyphenol, flavonoid, and alkaloid contents of plants may vary depending on environmental factors, soil type, sun exposure, rainfall, etc. [22]. As determined by the present study, the ethyl acetate fraction of G. edulis contained the highest phenol and flavonoid content, whereas the highest alkaloid content was observed in the crude methanol extract of G. edulis. The present study found comparatively lower phenolic content compared to the results of Ganesan et al. [23], who reported $3.98 \mathrm{mg} / \mathrm{mL}$ phenolic content. This variation may be due to the different sample collection locations, temperature conditions, and stress tolerance [24].

Oxidative stress is linked with the development of diabetes, and increases in accumulated fat in obese individuals through the activation of nicotinamide adenine dinucleotide phosphate (NADPH) oxidase and the impaired production of adipocytokines [25]. The antioxidant activity determined by the DPPH assay revealed high free radical scavenging activities in the ethyl acetate fraction and crude methanol extract of G. edulis, which occurred in a concentration-dependent manner (Figure A1). In the present study, strong DPPH free-radical scavenging ability was observed at $950 \mu \mathrm{g} / \mathrm{mL}$ of the ethyl acetate fraction $(21.06 \%)$ and crude methanol extract (19.52\%). This result contradicts a previous report in India [23]; compared to the present study, [16] reported lower DPPH free radical scavenging activity of the ethyl acetate fraction $(4.73 \%)$ and the crude methanol extract $(5.20 \%)$. The higher antioxidant 
activity observed in the present study may be due to the use of different extraction procedures and the differences in the phenolic compounds responsible for antioxidant activity.

The highest ABTS radical scavenging activity was observed in the ethyl acetate fraction of G. edulis, with a significant positive correlation being observed with total phenol content $(r=85)$. The reducing power of the sample depends on the available phenol and flavonoid contents of the sample [26]. In the present study, the ethyl acetate fraction exhibited the highest FRAP activity, which can be attributed to the presence of phenolic or flavonoid compounds with functional groups such as hydroxyl and carbonyl, which leads to the reduction or inhibition of oxidation. In contrast, Francavilla et al. reported the highest ABTS radical scavenging activity and ferric reducing antioxidant power in ethyl acetate fraction (0.43 and $0.809 \mathrm{mmol} \mathrm{TE} / \mathrm{g}$ ) of G.edulis collected seasonally in the Lesina Lagoon in Italy during the period of July [27]. Similarly, the ethyl acetate fraction of the present study exhibited higher reducing power compared to the previous study, which was collected in February. Therefore, differences in reducing power might be due to the seasonal variation.

The chelating power of the sample was determined using ferrozine reagent. Ferrozine can chelate with $\mathrm{Fe}^{2+}$, forming a red-colored ferrozine- $\mathrm{Fe}^{2+}$ complex [28]. According to the chelation activity, the highest FICA was observed in the ethyl acetate fraction. The ORAC assay determines the oxidative degradation of fluorescein in the presence of a free radical generator, such as an azo compound, for example, 2-azobis (2-amidinopropane) dihydrochloride [29]. The ORAC assay confirmed the high antioxidant capacity of the crude methanol extract of G. edulis. The high phenol and flavonoid contents of the ethyl acetate fraction are responsible for the potent antioxidant activity of G. edulis. Additionally, the presence of bioactive compounds such as 2,5-dimethylhexane-2,5-dihydroperoxide may also contribute to the antioxidant activity of G. edulis.

The inhibition of key metabolic carbohydrate-digesting enzymes is one of the main strategies to determine the antidiabetic activity of medicinal plants [30]. Therefore, natural bioactive compounds that reduce blood glucose levels by inhibiting the key metabolic enzymes ( $\alpha$-amylase, $\alpha$-glucosidase) and glucose absorption can be considered to be useful for the management of diabetes [31]. From the results, it is evident that the ethyl acetate fraction of G. edulis showed potential inhibitory activities with an effective dose for inhibition of $\alpha$-amylase ( $\mathrm{IC}_{50}: 279.48 \pm 5.62 \mu \mathrm{g} / \mathrm{mL}$ ) and $\alpha$-glucosidase $\left(\mathrm{IC}_{50}\right.$ : $87.92 \pm 1.62 \mu \mathrm{g} / \mathrm{mL}$ ) enzymes that are comparable to the standard drug acarbose (Table 3 ). The potential enzyme-inhibiting activity of the ethyl acetate fraction of G. edulis can be attributed to the presence of phytochemicals such as phenolic and flavonoid compounds. Senthil and Sudha [32] reported potent effective doses of inhibitory activity of $\alpha$-amylase $\left(\mathrm{IC}_{50}: 83 \mu \mathrm{g} / \mathrm{mL}\right)$ and $\alpha$-glucosidase $\left(\mathrm{IC}_{50}: 46 \mu \mathrm{g} / \mathrm{mL}\right.$ ) in an aqueous extract of $G$. edulis collected from India. The difference between the results obtained in the present study may be due to the different solvents used for the extraction method; in the present study, polyphenol was initially used to extract methanol, while the study conducted by Senthil and Sudha used water as a solvent.

The glucose diffusion inhibition test was carried out to evaluate the effect of methanol extract and fractions of G.edulis, with respect to its glucose retardation activity across the dialysis tube. The glucose entrapment ability of the crude methanol extract and four fractions were found to be significantly different at different times. Among them, the ethyl acetate fraction of G.edulis exhibited a significant glucose entrapment ability, which decreased the glucose movement into the external solution at $180 \mathrm{~min}$ compared to the control. The fact that the ethyl acetate fraction exhibited the highest inhibition of glucose diffusion may be due to the presence of insoluble fiber particles which entrap glucose molecules $[33,34]$. The dialysis tube method is a simple technique, which only determines the potential effect of methanol extract and fractions of G.edulis to retard the glucose diffusion through the normal dialysis membrane, whereas in the intestinal tract, transportation of glucose is assisted by glucose transporters incorporated with other molecules, in addition to the intestinal contractions [35]. Therefore, further in vivo studies should be carried out to determine the real effect of methanol extract and fractions of G. edulis on glucose diffusion. 
Chronic hyperglycemia in diabetic patients leads to the progression of microvascular and macrovascular complications. The high level of blood glucose leads to the formation of a complex between glucose and plasma proteins through non-enzymatic reactions and forms AGEs, which are associated with the pathogenesis of vascular complications in diabetes, renal failure, Alzheimer's disease, aging, and other chronic diseases [27]. The present study is the first to report the inhibitory activity of the methanol extract and four fractions of G. edulis on the formation of AGE products. The results of the study show that the lowest effective dose of inhibition of AGE formation was exhibited by chloroform ( $\mathrm{IC}_{50}: 258.23 \pm 3.24 \mu \mathrm{g} / \mathrm{mL}$ ) and ethyl acetate fractions $\left(\mathrm{IC}_{50}: 586.54 \pm 4.37 \mu \mathrm{g} / \mathrm{mL}\right)$ of G. edulis, compared to the standard drug rutin. The antiglycation activity of the chloroform and ethyl acetate fractions may be due to the presence of phenolic and flavonoid compounds, which are significantly correlated with anti-glycation activity [36].

Furthermore, GC-MS analysis of the ethyl acetate fraction of G. edulis revealed the presence of active compounds with strong antioxidant and antidiabetic activity, including $1 H$-Indole-2-carboxylic acid,6-(4-ethoxyphenyl)-3-methyl-4-oxo-4,5,6,7-tetrahydro-isopropyl ester and 2,5-dimethylhexane-2,5-dihydroperoxide. $1 H$-Indole-2-carboxylicacid,6-(4-ethoxyphenyl)-3-methyl4-oxo-4,5,6,7 tetrahydro-isopropyl ester is an indole derivative, which has insulin sensitizing and glucose lowering effects [17]. In addition, most of the indole derivatives act as an activator of the glycogen synthase enzyme, which is involved in the glycogen synthesis pathway [18], while 2,5-dimethylhexane-2,5-dihydroperoxide was identified to have antioxidant properties, which help to prevent the development of oxidative stress related to diabetes [14,15].

\section{Materials and Methods}

\subsection{Chemicals and Reagents}

Trolox, DPPH, trichloroacetic acid, ABTS, potassium persulpahte, 2,4,6-tripyridyl-s-triazine (TPTZ), soluble starch, Folin-Ciocalteu reagent, alpha glucosidase from Saccharomyces cerevisiae, gallic acid, acarbose, quercetin, aluminum chloride, $p$-nitrophenyl a-D-glucopyranoside, bovine serum albumin (BSA), and alpha-amylase were purchased from Sigma Aldrich (Allentown, PA, USA). The chemicals and reagents used for all experiments were of analytical grade.

\subsection{Collection of Algae Sample}

Permission to collect an algae sample was obtained from the Department of Wildlife Conservation (permit number WL/3/280/17). Marine red algae (Gracillaria edulis) was manually collected from Kalpitiya, Sri Lanka ( $6^{0} 4^{\prime} 54.19^{\prime \prime} N ; 80^{0} 8^{\prime} 51.78^{\prime \prime}$ E). The samples were identified based on their morphological characteristics by Dr. Kalpa Samarakoon. The collected samples were cleaned and washed with fresh water to remove salt, sand, and other debris. The samples were freeze-dried using a LyoBeta freeze drying unit (Telstar), powdered, and stored at $-20^{\circ} \mathrm{C}$ until further use.

\subsection{Preparation of Gracillaria edulis Extract and Its Solvent Fractions}

The extraction procedure was conducted according to the method of Lakmal et al., [37] with some modifications. Homogenized G. edulis powder was extracted three times using $70 \%$ methanol, and was then subjected to sonication (Clifton, 91695) at $25^{\circ} \mathrm{C}$. Polyphenols were separated using $70 \%$ ethanol $(v / w \%=1: 25)$ and allowed to stand overnight. The supernatant was separated by centrifugation (Centurion K241R, Surrey, UK) at 12,000 rpm before being filtered to separate the polyphenol portion. A portion of the de-polysaccharide methanol extract was subjected to sequential solvent-solvent partition with hexane, chloroform, and ethyl acetate, respectively. Finally, the four fractions and crude methanol extract were dried under vacuum (BUCHI, Rotavapor, R-300, New Castle, DE, USA) and used to conduct the assays. 


\subsection{Quantification of Phenol, Flavonoid, and Alkaloid Contents}

The total phenol content of the methanol extract and fractions was evaluated using the Folin-Ciocalteu method $(n=4)$. Different concentrations $(5,10$, and $20 \mathrm{mg} / \mathrm{mL})$ of methanol extract and the four fractions were prepared by diluting with distilled water. The sample $(20 \mu L)$, diluted Folin-Ciocalteu reagent $(110 \mu \mathrm{l})$, and $10 \%$ sodium carbonate solution $(70 \mu \mathrm{L})$ were mixed and incubated at room temperature for $30 \mathrm{~min}$. Absorbance was measured at $765 \mathrm{~nm}$. Gallic acid was used as the standard, and results were expressed as $\mathrm{mg}$ gallic acid equivalent per $1 \mathrm{~g}$ of dry weight of the extract/fraction [38].

The total flavonoid content of the methanol extract and fractions $(n=4)$ of $G$. edulis were evaluated by the aluminium chloride method [39]. Different concentrations $(5,10$, and $20 \mathrm{mg} / \mathrm{mL})$ of the methanol extract and fractions were prepared by diluting with methanol. The absorbance before adding the $2 \%$ aluminum chloride was taken at $415 \mathrm{~nm}$. A total of $100 \mu \mathrm{l}$ of $2 \%$ aluminium chloride solution was added and incubated at room temperature for $10 \mathrm{~min}$. A plate reading was recorded at $415 \mathrm{~nm}$. Quercetin was used as a standard, and results was expressed as mg quercetin equivalent per $1 \mathrm{~g}$ of dry weight of the extract or reaction.

The total alkaloid content of the methanol extract and fractions $(n=4)$ of $G$. edulis was evaluated by the method described by Sreevidya et al. [40] with some modifications. Different concentrations $(5,10$, and $20 \mathrm{mg} / \mathrm{mL})$ of the methanol extract and fractions of G. edulis were prepared by diluting with $95 \%$ ethanol and $\mathrm{pH}$ was adjusted to $2-2.5$. A total of $100 \mu \mathrm{L}$ of sample was mixed with $200 \mu \mathrm{L}$ of Dragendorff reagent and centrifuged at $5000 \mathrm{rpm}$ for $5 \mathrm{~min}$. The precipitate was separated and washed with $95 \%$ ethanol. A total of $200 \mu \mathrm{L}$ of $1 \%$ disodium sulfide solution was added, and the resulting brownish-black precipitate was centrifuged at $5000 \mathrm{rpm}$ for $5 \mathrm{~min}$. The supernatant was discarded and the pellet was dissolved in concentrated $\mathrm{HNO}_{3}$ and diluted up to $1 \mathrm{~mL}$ with distilled water. A.total of $100 \mu \mathrm{L}$ of the solution was pipetted and mixed with $500 \mu \mathrm{L}$ of $3 \%$ thiourea. Absorbance was recorded at $460 \mathrm{~nm}$. Piperine was used as the standard, and the results were expressed as $\mathrm{mg}$ piperine equivalent per $1 \mathrm{~g}$ of dry weight of extract or fraction.

\subsection{In Vitro Antioxidant Activity}

\subsubsection{DPPH Radical Scavenging Activity}

The DPPH scavenging activity of the extracts and fractions of G. edulis $(n=4)$ was determined using the method described by Blois [41]. A concentration series (3.75, 1.875, 0.938, 0.469, 0.234, 0.1170, and $0.058 \mathrm{mg} / \mathrm{mL}$ ) of algal samples was prepared in methanol. A total of $50 \mu \mathrm{L}$ of sample was mixed with methanol and absorbance before adding the DPPH solution was taken at $517 \mathrm{~nm}$. Subsequently, DPPH solution was added and incubated in a dark area for $15 \mathrm{~min}$ at $25^{\circ} \mathrm{C}$. After incubation, a plate reading was taken at $517 \mathrm{~nm}$. Trolox was used as the standard, and the DPPH scavenging activity was expressed as mg Trolox equivalent per $1 \mathrm{~g}$ of dry weight of extract or fraction.

\subsection{2. $\mathrm{ABTS}^{+}$Radical Scavenging Activity}

The $\mathrm{ABTS}^{+}$scavenging activity was measured using the method described by Re et al. [42]. Before conducting the experiment, $\mathrm{ABTS}^{+}$radical was produced by incubating ABTS tablet $(10 \mathrm{mg})$ with $2.5 \mathrm{mM}$ potassium persulpahte solution $(2.5 \mathrm{~mL})$. Five different concentrations $(0.5,0.25,0.125,0.063$, and $0.031 \mathrm{mg} / \mathrm{mL})$ of the methanol extract and fractions $(n=4)$ were diluted in $50 \mathrm{mM}$ PBS (pH 7.4) and absorbance before adding ABTS reagent was taken at $734 \mathrm{~nm}$. A total of $40 \mu \mathrm{L}$ of diluted ABTS+ reagent was added and incubated for $10 \mathrm{~min}$ at room temperature. After incubation, a plate recording was taken at $734 \mathrm{~nm}$. Trolox was used as the standard antioxidant and the results were expressed as mg Trolox equivalent per $1 \mathrm{~g}$ of dry weight of extract or fraction. 


\subsubsection{Ferric Reducing Antioxidant Power (FRAP)}

Ferric reducing antioxidant power was measured according to the method of Benzie and Szeto [43], with some modifications. Different concentrations $(5,2.5,1$, and $0.5 \mathrm{mg} / \mathrm{mL})$ of the methanol extract and four fractions ( $n=4)$ were diluted in $300 \mathrm{mM}$ acetate butter ( $\mathrm{pH}$ 3.6). Before conducting the experiment, FRAP reagent was prepared using $300 \mathrm{mM}$ acetate buffer ( $\mathrm{pH}$ 3.6), $10 \mathrm{mM}$ of 2,4,6-tripyridyl-s-triazine (TPTZ), and $20 \mathrm{mM} \mathrm{FeCl}_{3}$ solution mixed with a ratio of 10:1:1 and incubated at $37^{\circ} \mathrm{C}$ for 10 min. The FRAP reagent $(150 \mu \mathrm{L})$, acetate buffer $(30 \mu \mathrm{L})$, and algae samples $(20 \mu \mathrm{L})$ were mixed together and incubated for $8 \mathrm{~min}$ at room temperature. After incubation, a plate reading was made at $600 \mathrm{~nm}$. Trolox was used as the standard and the results were expressed as mg Trolox equivalent per $1 \mathrm{~g}$ dry weight of extract or fraction.

\subsubsection{Ferrous Iron Chelating Capacity (FICC)}

The ferrous iron chelating capacity (FICC) was measured using the method of Carter [44], with some modifications. Five different concentrations $(6.25,5,3.13,2.5$, and $1.56 \mathrm{mg} / \mathrm{mL})$ of the methanol extract and fractions were diluted in distilled water, $1 \mathrm{mM}$ ferrozine (4,4-disulfonic acid sodium salt) solution, and $1 \mathrm{mM}$ ferrous sulphate solution $(n=4)$. Algal samples $(100 \mu \mathrm{L}), \mathrm{FeSo}_{4}$ solution $(20 \mu \mathrm{L})$, and distilled water $(40 \mu \mathrm{L})$ were mixed, and absorbance before adding ferrozine solution was taken at $562 \mathrm{~nm}$. Ferrozine solution $(40 \mu \mathrm{L})$ was mixed and incubated for $10 \mathrm{~min}$ at room temperature. A plate reading was recorded at $562 \mathrm{~nm}$ and the results were expressed as mg EDTA equivalent per $1 \mathrm{~g}$ of dry weight of the extract or fraction.

\subsubsection{Oxygen Radical Absorbance Capacity (ORAC)}

The ORAC was measured using the method of Ou et al. [45], with modifications. Different concentrations $(5,2.5$, and $1.25 \mathrm{mg} / \mathrm{mL})$ of the extract and fractions were diluted in phosphate buffer saline (75 mM, pH 7.4). Before conducting the experiment, flourcein (16 mg in $100 \mathrm{~mL}$ of phosphate buffer saline) and AAPH [2,2'-azobis (2-amidinopropane) dihydrochloride] solutions (40 mg in $1 \mathrm{~mL}$ of phosphate buffer saline) were prepared. The reaction mixture $(200 \mu \mathrm{L})$, containing algal samples $(10 \mu \mathrm{L})$, PBS $(40 \mu \mathrm{L})$ and fluorescein solution $(100 \mu \mathrm{L})$, was preincubated at $37^{\circ} \mathrm{C}$ for 5 min. After incubation, AAPH solution was added and absorbance recordings were made at excitation and emission wavelengths of $494 \mathrm{~nm}$ and $535 \mathrm{~nm}$, respectively, at $1 \mathrm{~min}$ intervals for $35 \mathrm{~min}$. Trolox was used as the standard, and the results were expressed as mg Trolox equivalent per $1 \mathrm{~g}$ dry weight of the sample.

\subsection{In Vitro $\alpha$-amylase and $\alpha$-glucosidase Inhibitory Assay}

\subsubsection{Alpha-Amylase Inhibitory Activity}

The anti-amylase activity was measured using the method of Bernfeld [46], with modifications $(n=4)$. Various concentrations of the algal extract $(400,200,100,50,25$, and $12.5 \mu \mathrm{g} / \mathrm{mL})$ and acarbose $(200,100,50,25,12.5$, and $6.25 \mu \mathrm{g} / \mathrm{mL})$ were preincubated with starch $(40 \mu \mathrm{L})$ and sodium acetate buffer $(710 \mu \mathrm{L})$ at $40{ }^{\circ} \mathrm{C}$ in a shaking water bath (Wise Bath, WSB-30, Wertherim, Germany) for $10 \mathrm{~min}$. The $\alpha$-amylase enzyme solution $(50 \mu \mathrm{l}: 1 \mathrm{mg} / \mathrm{mL})$ was added and incubated again for $15 \mathrm{~min}$. After incubation, $500 \mu \mathrm{L}$ of 3,5-dinitrosalicylic acid (DNS) solution was added and boiled for 5 min until color developed and was then kept in an ice bath to cool. The absorbance was recorded at $540 \mathrm{~nm}$ using a SpectraMax Plus 384 instrument (Molecular Devices, San Jose, CA, USA). Another experiment was carried out in an identical way by replacing enzyme solution with acetate buffer to determine the absorbance produced by the sample itself. A control experiment was conducted by replacing extracts with $100 \mathrm{mM}$ sodium acetate buffer. Acarbose was used as the standard and percentage $\alpha$-amylase inhibition was calculated. 


\subsubsection{Alpha-Glucosidase Inhibitory Activity}

The $\alpha$-glucosidase inhibition assay was performed according to the method of Matsui et al. [47], with some modifications. Different concentrations of algal samples (133.3, 66.6, 33.3, 16.6, 8.3, and $4.16 \mu \mathrm{g} / \mathrm{mL})$ or acarbose $(2.5,1.25,0.625,0.313,0.156,0.078$, and $0.039 \mu \mathrm{g} / \mathrm{mL})$ in acetate buffer, and $p$-nitrophenyl-a-D-glucopyranoside (PNPG) solution were incubated at $37^{\circ} \mathrm{C}$ for $5 \mathrm{~min}$. After measuring the absorbance, $25 \mathrm{mU} / \mathrm{mL}$ of $\alpha$-glucosidase was added and incubated at $37^{\circ} \mathrm{C}$ for $35 \mathrm{~min}$. After incubation, $10 \% \mathrm{NaCO}_{3}$ solution was added to stop the reaction. The absorbance was then recorded at $400 \mathrm{~nm}$. The reaction mixture without extract was used as the control and anti-glucosidase activity (\% inhibition) was calculated.

\subsubsection{Glucose Diffusion Inhibitory Activity}

Glucose diffusion inhibitory activity was determined using a dialysis bag and a glucose oxidase kit [48]. Initially, a dialysis membrane (D9777) was activated according to the manufacturer's instructions. Briefly, $2 \mathrm{~mL}$ of the algae sample $(1 \mathrm{mg} / \mathrm{mL})$ was placed in a dialysis tube with $2 \mathrm{~mL}$ of $0.22 \mathrm{mM}$ glucose solution. Subsequently, the dialysis tube was dipped in a beaker containing $80 \mathrm{~mL}$ of $0.15 \mathrm{M} \mathrm{NaCl}$ and $20 \mathrm{~mL}$ of distilled water and was shaken constantly at $150 \mathrm{rpm}$ at $37^{\circ} \mathrm{C}$. The glucose concentration $(\mu \mathrm{g} / \mathrm{mL})$ in the external solution was measured at $30 \mathrm{~min}$ intervals for $3 \mathrm{~h}$ using a GAGO-20 glucose oxidase kit (Sigma Aldrich). Acarbose and distilled water were used as the standard and the control, respectively.

\subsubsection{Antiglycation Activity}

Antiglycation activity was measured using the method of Matsuura et al. [49], with some modifications. Algal extracts were prepared by dissolving with phosphate buffer saline. Bovine serum albumin $(80 \mu \mathrm{L})$, algae extract $(80 \mu \mathrm{L}), 400 \mathrm{mM}$ glucose $(360 \mu \mathrm{L})$, and $50 \mathrm{mM}$ PBS $(\mathrm{pH} 7.4,480 \mu \mathrm{L})$ was incubated at $60^{\circ} \mathrm{C}$ for $50 \mathrm{~h}$. After incubation, the solution was cooled and $200 \mu \mathrm{l}$ of $50 \%$ trichloroacetic acid was added and centrifuged at $15,000 \mathrm{rpm}$ at $4{ }^{\circ} \mathrm{C}$ for $4 \mathrm{~min}$. The resulting precipitate was dissolved in PBS (pH 10) and absorbance values were recorded at an excitation wavelength of $370 \mathrm{~nm}$ and emission wavelength of $440 \mathrm{~nm}$ (Amino-Bowman Series 2, Thermo Spectronic, Fitchburd, WI, USA). A sample negative was carried out in the same way, however without adding glucose. A sample control was conducted by replacing algal extracts with $50 \mathrm{mM}$ PBS. Rutin was used as the standard and antiglycation activity (\% inhibition) was calculated.

\subsection{GC-MS Analysis of Extract and Solvent Fractions}

The GC-MS analysis was performed on active fraction (ethyl acetate fraction) using a 5975C gas chromatograph (Agilent Technologies, Palo Alto, CA, USA) and an HP-5MS capillary column $(30 \mathrm{~m} \times 25 \mu \mathrm{m}$ with a film thickness of $0.25 \mu \mathrm{m})$. Briefly, the sample $(1 \mu \mathrm{L})$ was injected into the HP-5MS capillary column and was exposed to a temperature of $70^{\circ} \mathrm{C}$ for $2 \mathrm{~min}$; then, the temperature was increased from $70{ }^{\circ} \mathrm{C}$ to $200^{\circ} \mathrm{C}$ at a rate of $3{ }^{\circ} \mathrm{C} / \mathrm{min}^{-1}$ and held at $200{ }^{\circ} \mathrm{C}$ for $15 \mathrm{~min}$. Helium was used as the carrier gas with a flow rate of $1 \mathrm{~mL} / \mathrm{min}$. After obtaining the chromatogram, the mass spectrum of the unknown component was identified using the NIST (NIST 17) library [50].

\subsection{Statistical Analysis}

Statistical analysis of each experiment was carried out using the Minitab 17 software (Cubic Computing Pvt. Ltd., Bangalore, India) and Microsoft Excel 2016. All the experiments were performed using four replicates. Mean and standard deviation were calculated using standard equations. One-way ANOVA was used to determine the significant differences between the methanol extract and the fractions of G. edulis. p-values less than 0.05 were considered significant. The Pearson's correlation coefficient was used for the correlation analysis. 


\section{Conclusions}

The present study found that G. edulis exhibited promising hypoglycemic activity by inhibiting key carbohydrate-digesting enzymes, glucose absorption, and the formation of antiglycation end products. Although antioxidant activity and enzyme inhibitory activity are stronger in commercial drugs than in G. edulis methanol extracts and its fractions, the hypoglycemic potential of G. edulis was evident in the present study. GC-MS analysis further confirmed the presence of bioactive compounds rich in antioxidants and antidiabetic properties. The ethyl acetate fraction exhibited promising antiglycation, and hypoglycemic potential. Hence, 3T3-L1 mature adipocytes and animal models are required to confirm anti-obesity and antidiabetic potentials of G. edulis. Isolation of active compounds for the development of new drugs is also warranted.

Author Contributions: Conceptualization, L.D.C.P., P.R. and K.W.S.; methodology, L.D.C.P., P.R., and K.W.S.; software, T.L.G.; formal analysis, T.L.G. and P.R.; investigation, T.L.G. and P.R.; data curation, T.L.G.; writing-original draft preparation, T.L.G.; writing-review and editing, L.D.C.P., and K.W,S.; supervision, L.D.C.P., P.R. and K.W.S.; project administration, L.D.C.P.; funding acquisition, L.D.C.P. All authors read and approved the final manuscript.

Funding: This research was funded by the University of Sri Jayewardenepura, Sri Lanka (ASP/01/RE/SCI/2017/50).

Conflicts of Interest: The authors declare no conflict of interest.

\section{Appendix A}

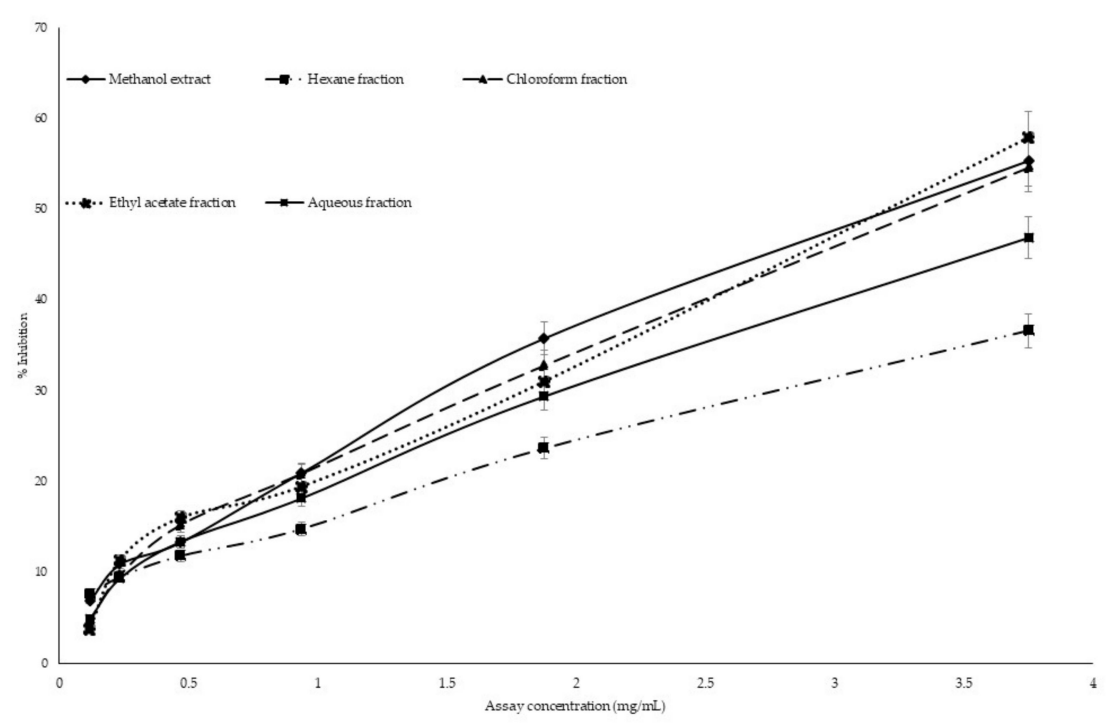

Figure A1. Dose dependent DPPH (1,1-diphenyl-2-picrylhydrazine) radical scavenging activity of methanol extract and fractions of Gracillaria edulis. Data presented as mean \pm standard deviation $(n=4)$. 


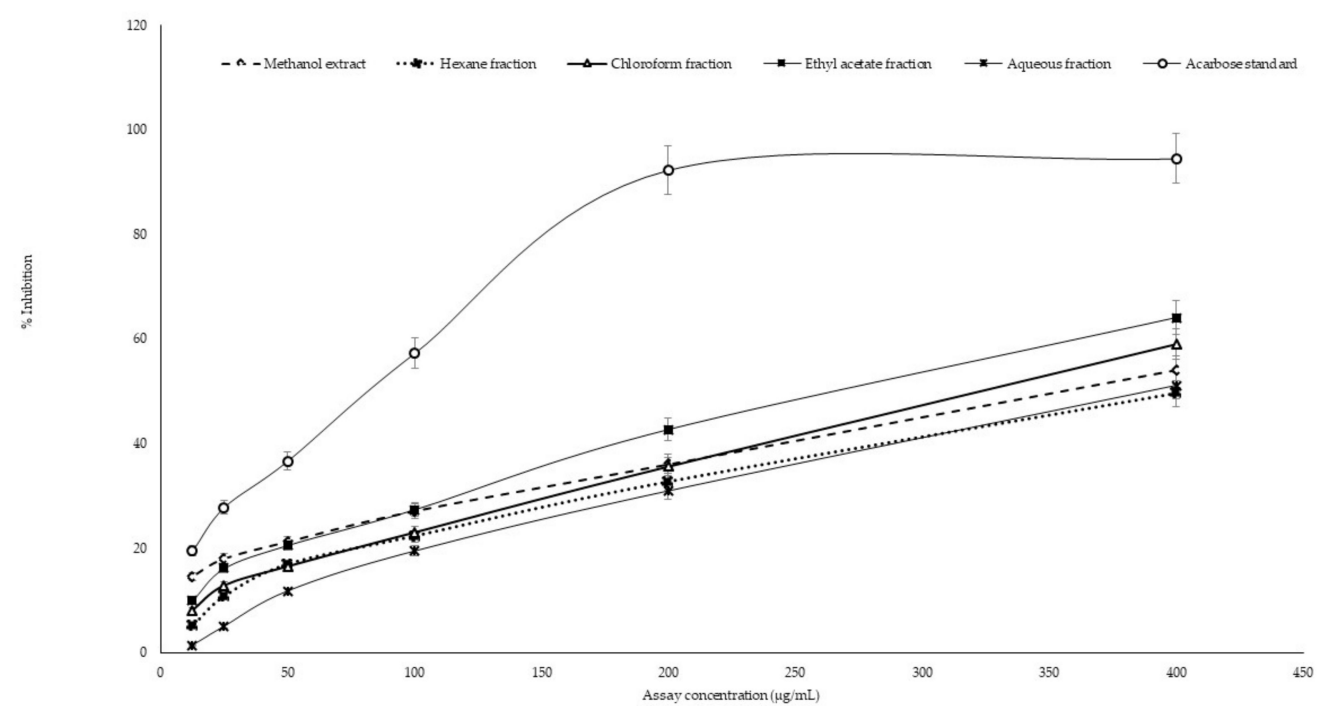

Figure A2. Percentage inhibition of $\alpha$-amylase by G. edulis methanol extract and its fractions. Results are expressed as mean \pm standard deviation $(n=4)$.

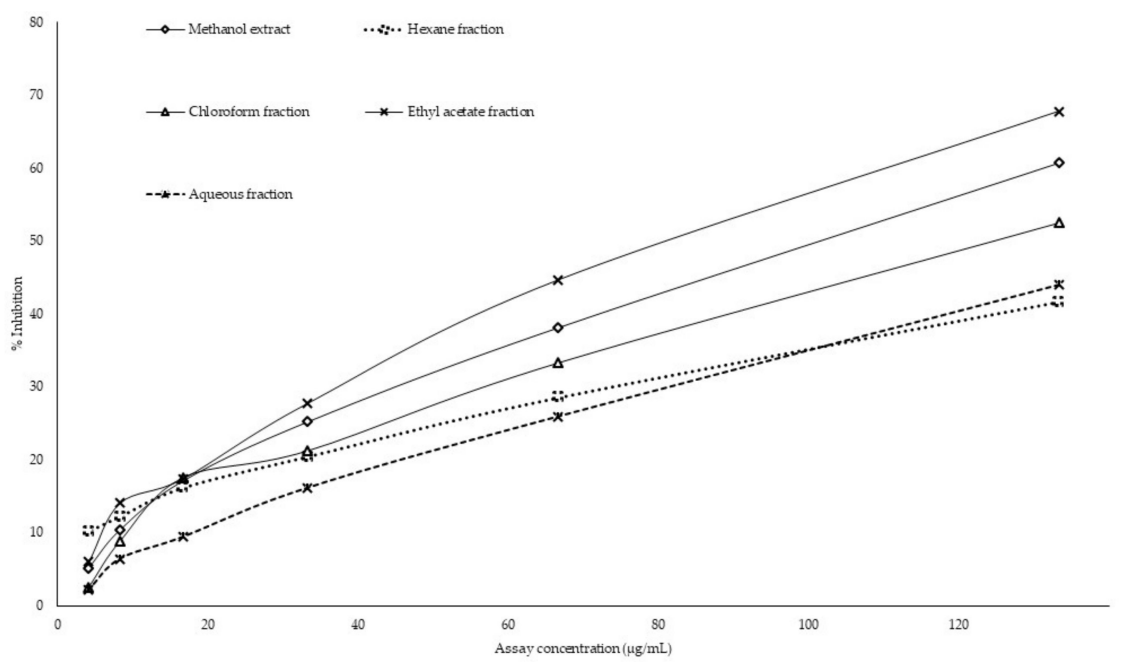

Figure A3. Dose-response relationship of methanol extract and its fractions of G. edulis for anti glucosidase activity. Results are expressed as mean \pm standard deviation $(n=4)$.

Table A1. Effect of methanol extract and its fractions of Gracillaria edulis $(1000 \mu \mathrm{g} / \mathrm{mL})$ on glucose diffusion.

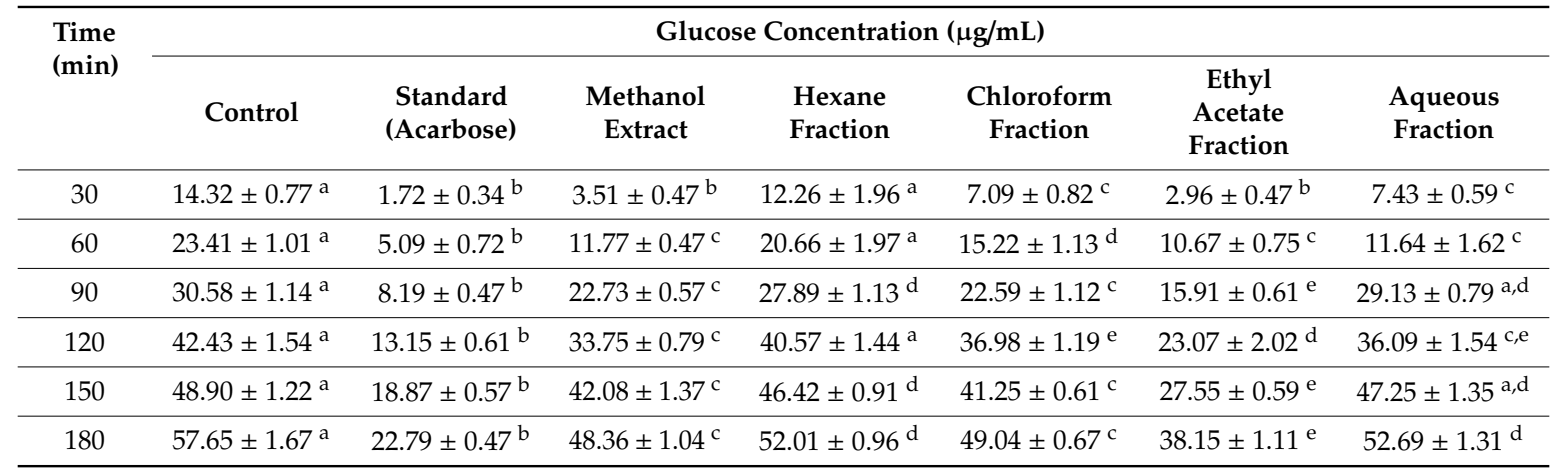

Results are expressed as mean \pm standard deviation $(n=4)$. Mean values in a column superscripted by different letters $\left({ }^{\mathrm{a}-\mathrm{e}}\right)$ are significantly different at $p<0.05$. 


\section{References}

1. American Diabetes Association. Diagnosis and classification of diabetes mellitus. Diab. Care 2013, 36, 67-74. [CrossRef] [PubMed]

2. World Health Organization. Diabetes. 2016. Available online: http:/www.who.int/mediacentre/factsheets/ fs312/en/ (accessed on 31 January 2019).

3. Jenum, A.K.; Diep, L.M.; Holmboe-Ottesen, G.; Holme, I.M.; Kumar, B.N.; Birkeland, K.I. Diabetes susceptibility in ethnic minority groups from Turkey, Vietnam, Sri Lanka and Pakistan compared with Norwegians - the association with adiposity is strongest for ethnic minority women. BMC Pub. Heal. 2012, 12, 1-50. [CrossRef] [PubMed]

4. Chawla, A.; Chawla, R.; Jaggi, S. Microvasular and macrovascular complications in diabetes mellitus: Distinct or continuum. Indian J. Endocrinol. Metab. 2016, 20, 546-551. [CrossRef] [PubMed]

5. Eleazu, C.O. The concept of low glycemic index and glycemic load foods as panacea for type 2 diabetes mellitus. Afr. Health Sci. 2016, 16, 468-479. [CrossRef] [PubMed]

6. Nair, S.S.; Kavrekar, V.; Mishra, A. In vitro studies on alpha amylase and alpha glucosidase inhibitory activities of selected plant extracts. Eur. J. Exp. Biol. 2013, 3, 128-132.

7. Ferná1ndez-Sánchez, A.; Madrigal-Santillán, E.; Bautista, M.; Esquivel-Soto, J.; Morales-González, A.; Esquivel-Chirino, C.; Durante-Montiel, I.; Sánchez-Rivera, G.; Valadez-Vega, C.; Morales-González, J.A. Inflammation, Oxidative Stress, and Obesity. Int. J. Mol. Sci. 2011, 12, 3117-3132. [CrossRef]

8. Wright, E., Jr.; Glass, L.C. Oxidative stress in type 2 diabetes: The role of fasting and postprandial glycaemia. Int. J. Clin. Pract. 2006, 60, 308-314.

9. Pal, A.; Kamthania, M.C.; Kumar, A. Bioactive Compounds and Properties of Seaweeds-A Review. Biotechnol. Bioinform. 2014, 1, 1-11.

10. De Souza, M.D.F.V.; Barbosa-filho, J.M.; Batista, L.M. Bioactivities from Marine Algae of the Genus Gracilaria. Int. J. Mol. Sci. 2011, 12, 4550-4573.

11. Fernando, S.; Sanjeewa, A. Preliminary screening of two marine algae and sea grass harvested from Sri Lankan waters against the LPS-induced inflammatory responses in RAW 264.7 macrophages and in vivo Zebra fish embryo model. J. Natl. Sci. Found. 2018, 46, 117-124. [CrossRef]

12. Koneri, R.; Jha, D.K. A Study on the Type II Antidiabetic Activity of Methanolic Extract of Marine Algae, Gracilaria edulis and Sargassum polycystum. Int. J. Pharm. Sci. Rev. Res. 2017, 47, 154-159.

13. Patra, S.; Muthuraman, M.S. Gracilaria edulis extract induces apoptosis and inhibits tumor in Ehrlich Ascites tumor cells in vivo. BMC Complementary Altern. Med. 2013, 13, 331-335. [CrossRef] [PubMed]

14. Al-Marzoqi, A.H.; Hameed, I.M.; Ali Idan, S. Analysis of bioactive chemical components of two medicinal plants (Coriandrum sativum and Melia azedarach) leaves using gas chromatography-mass spectrometry (GC-MS). Afr. J. Biotchenol. 2015, 14, 2812-2830.

15. Villalva, M.; Jaime, L.; Aguado, E.; Nieto, J.A.; Reglero, G.; Santoyo, S. Anti-Inflammatory and Antioxidant Activities from the Basolateral Fraction of Caco-2 Cells Exposed to a Rosmarinic Acid Enriched Extract. J. Agric. Food Chem. 2018, 66, 1167-1174. [CrossRef]

16. Jalill, A.; Dh, R.; Jalill, A. GC-MS analysis of Calendula officinalis and cytotoxic effects of its flower crude extract on human epidermoid larynx carcinoma (hep-2). World J. Pharm. Pharm. Sci. 2014, 3, 237-275.

17. Ali, N.; Dar, B.; Farooqui, M. Chemistry and Biology of Indoles and Indazoles: A Mini-Review. Med. Chem. 2012, 13, 1-16.

18. World Intellectual Property Organization. Indole and Indazole derivatives as glycogen synthase activators. Int. Appl. Publ. Under Pat. Coop. Treaty 2011, 74, 1-10.

19. Zeng, H.; Chen, X.; Liang, J. In vitro antifungal activity and mechanism of essential oil from fennel (Foeniculum vulgare L.) on dermatophyte species. J. Med. Microbiol. 2015, 64, 93-103. [CrossRef]

20. Agirbas, H.; Budak, F. Synthesis and structure-antibacterial activity relationship studies of 4-substituted phenyl -4, 5-dihydrobenzo [f] [1, 4] oxazepin-3 (2H)-thiones. Med. Chem. Res. 2011, 20, 1170-1180. [CrossRef]

21. Peng, W.; Li, D.; Ohkoshi, M. Characteristics of antibacterial molecular activities in poplar wood extractives. Saudi J. Biol. Sci. 2017, 24, 399-404. [CrossRef]

22. Pandey, K.B.; Rizvi, S.I. Plant polyphenols as dietary antioxidants in human health and disease. J. Clin. Investig. 2009, 2, 270-278. [CrossRef] 
23. Ganesan, P.; Kumar, C.S.; Bhaskar, N. Antioxidant properties of methanol extract and its solvent fractions obtained from selected Indian red seaweeds. Bioresour. Technol. 2008, 99, 2717-2723. [CrossRef] [PubMed]

24. Fellah, F.; Louaileche, H.; Touati, N. Seasonal variations in the phenolic compound content and antioxidant activities of three selected species of seaweeds from Tiskerth islet, Bejaia, Algeria. J. Mater. Environ. Sci. 2017, 8, 4451-4456. [CrossRef]

25. Marseglia, L.; Manti, S.; Angelo, G.D.; Nicotera, A.; Parisi, E.; Rosa, G.D.; Gitto, E.; Arrigo, T. Oxidative Stress in Obesity: A Critical Component in Human Diseases. Int. J. Mol. Sci. 2015, 16, 378-400. [CrossRef] [PubMed]

26. Sampath, S.G.; Dheeba, K.P.; Sivakumar, R. In vitro anti-diabetic, antioxidant and anti- inflammatory activity of Clitoria Ternatea, L. Artic. Int. J. Pharm. Pharm. Sci. 2014, 6, 342-347.

27. Francavilla, M. The red seaweed Gracilaria gracilis as a multi products source. Mar. Drugs 2013, 11, 3754-3776. [CrossRef] [PubMed]

28. Ranasinghe, P. Antioxidant Activity of Caryota urens L. (Kithul) Sap. Trop. Agric. Res. 2012, 23, 117-125. [CrossRef]

29. Bernaert, N. Antioxidant capacity, total phenolic and ascorbate content as a function of the genetic diversity of leek (Allium ampeloprasum var porrum). Food Chem. 2012, 134, 669-677. [CrossRef]

30. Gulati, V.; Harding, I.H.; Palombo, E.A. Enzyme inhibitory and antioxidant activities of traditional medicinal plants: Potential application in the management of hyperglycemia. Bmc Complementary Altern Med. 2012, 12, 2-9.

31. Unnikrishnan, P.S.; Suthindhiran, K.; Jayasri, M.A. Antidiabetic potential of marine algae by inhibiting key metabolic enzymes. J. Front. Life Sci. 2015, 8, 148-159. [CrossRef]

32. Senthil Kumar, P.; Sudha, S. Evaluation of Alpha-Amylase and Alpha-Glucosidase Inhibitory Properties of Selected Seaweeds from Gulf of Mannar. Irjponline. Com. 2012, 3, 128-130.

33. Gallagher, A.M.; Flatt, P.R.; Duffy, G.; Abdel-Wahab, Y.H.A. The effects of traditional antidiabetic plants on in vitro glucose diffusion. Nutr. Res. 2003, 23, 413-424. [CrossRef]

34. Sudasinghe, H.P.; Peiris, D.C.P. Hypoglycemic and hypolipidemic activity of aqueous leaf extract of Passiflora suberosa L. Peer J. 2018, 6, e4389.

35. Navale, A.M.; Paranjape, A.N. Glucose transporters: physiological and pathological roles. Biophys Rev. 2016, 8, 5-9. [CrossRef] [PubMed]

36. Grzegorczyk-Karolak, I.; Goła, G.; Gburek, J.; Wysokin, H.; Matkowski, A. Inhibition of Advanced Glycation End-Product Formation and Antioxidant Activity by Extracts and Polyphenols from Scutellaria alpina L. and S. altissima L. Molecules 2016, 21, 739. [CrossRef] [PubMed]

37. Lakmal, H.; Samarakoon, K.; Lee, W.; Lee, J.; Abeytunga, D.; Lee, H.; Jeon, Y. Anticancer and antioxidant effects of selected Sri Lankan marine algae. J. Natl. Sci. Found. Sri Lanka 2014, 42, 117-124. [CrossRef]

38. Singleton, V.L.; Orthofer, R.; Lamuela-Raventos, R.M. Analysis of total phenols and other oxidation substrates and antioxidants by means of Folin-Ciocaltue reagent. Methods Enzym. 1999, 299, 152-178.

39. Chang, C.C.; Yang, M.H.; Ucen, H.M.; Chern, J.C. Estimation of total flavonoid content in propolis by complementary colorimetric method. J. Food Drug Anal. 2002, 10, 178-182.

40. Sreevidya, N.; Mehrotra, S. Spectrometric method for estimation of precipitable with Dragendorff's reagent in plant material. J. Aoac Int. 2003, 36, 1124-1127.

41. Blois, M.S. Antioxidant determination by use of stable free radical. Nature 1958, 181, 1199-1200. [CrossRef]

42. Re, R.; Pellegrini, N.; Proteggente, A.; Pannala, A.; Yang, M.; Rice-Evans, C. Antioxidant activity applying an improved ABTS radical cation decolorization Assay. Free Rad. Biol. Med 1999, 26, 1231-1237. [CrossRef]

43. Benzie, I.F.F.; Szeto, Y.T. Total antioxidant capacity of teas by the ferric reducing/antioxidant power assay. J. Agric. Food Chem. 1999, 47, 633-636. [CrossRef] [PubMed]

44. Carter, P. Spectrophotometric determination of serum iron at the sub-microgram level with a new reagent ferrozine. Annu. Biochem. 1971, 40, 450-458. [CrossRef]

45. Ou, B.; Hampsch-Woodill, M.; Prior, R.L. Development and validation of an improved oxygen radical absorbance capacity assay using fluorescein as the fluorescent probe. J. Agric. Food Chem. 2001, 49, 4619-4626. [CrossRef] [PubMed]

46. Bernfeld, P. Amylases, alpha and beta. In Methods in Enzymology; Colowick, S.P., Kaplan, N.O., Eds.; Academic Press: New York, NY, USA, 1955; Volume 1, pp. 149-158. 
47. Matsui, T.; Ueda, T.; Oki, T.; Sugita, K.; Terahara, N.; Matsumoto, K. $\alpha$-Glucosidase inhibitory action of natural acylated anthocyanins. J. Agric. Food Chem. 2001, 49, 1948-1951. [CrossRef]

48. Roy, A.; Mahalingam, M.G. The in-vitro antidiabetic activity of Phoenix roebelenii leaf extract. Int. J. Green Pharm. 2017, 11, 884-890.

49. Matsuura, N.; Aradate, T.; Sasaki, C.; Kojima, H.; Ohara, M.; Hasegawa, J.; Ubukata, M. Screening system for the Maillard reaction inhibitor from natural product extracts. J. Health Sci. 2002, 48, 520-526. [CrossRef]

50. Jerkovi, I. Phytochemical study of the headspace volatile organic compounds of fresh algae and sea grass from the Adriatic Sea (single point collection). PLOS ONE 2008, 13, e0196462.

Sample Availability: Samples of the compounds are available from the authors.

(C) 2019 by the authors. Licensee MDPI, Basel, Switzerland. This article is an open access article distributed under the terms and conditions of the Creative Commons Attribution (CC BY) license (http://creativecommons.org/licenses/by/4.0/). 